\title{
WeLL-KNOWN TRAde MaRKS, Foreign INVESTMENT AND LOCAL INDUSTRY: A COMPARISON OF CHINA AND INDONESIA
}

\section{Christoph Antons*}

\section{KUI HUA WANG**}

Strengthened protection for well-known trade marks in accordance with the TRIPS Agreement is an important issue for developing countries, which has led to trade pressures from industrialised nations in the past. 'Trade mark squatting', referring to the registration in bad faith of foreign well-known marks in order to sell them back to their original owners, is a much discussed phenomenon in this context. This article outlines the history and development of well-known trade marks and the applicable law in China and Indonesia. It looks not just at foreign and international brands subjected to 'trade mark squatting', but also at how local enterprises are using the system. Rather remarkably in view of the countries' turbulent histories, local well-known marks have a long history and are well respected for their range of products. They are not normally affected by the 'trade mark squatting' phenomenon and are rarely the subject of disputes. Enhanced protection under the TRIPS Agreement is especially relevant for international brands and the article shows the approaches in the two countries. In China, government incentives assist the proliferation of nationally well-known and locally 'famous' marks. In Indonesia, lack of implementing legislation has left the matter of recognition to the discretion of the courts.

\footnotetext{
* Christoph Antons, Chair in Law, School of Law, Deakin University, Geelong; Chief Investigator, Australian Research Council Centre of Excellence for Creative Industries and Innovation; Affiliated Research Fellow, Max Planck Institute for Intellectual Property and Innovation, Munich; Senior Fellow, Center for Development Research, University of Bonn. This research was supported under the Australian Research Council's Discovery Projects funding scheme (project number DP130100213).

** Kui Hua Wang, Senior Lecturer, School of Law, Deakin University, Geelong.
} 


\section{INTRODUCTION}

Trade mark law has been regarded as 'in principle a clearly defined subject' protecting registered marks against registration of an identical or confusingly similar mark for the same or similar products. ${ }^{1}$ The subject of discussions at the international level has been the question of the protection of non-registered marks and, in particular, the extension of the protection to dissimilar products. In a globalised market using enhanced media dissemination and worldwide marketing, brands are now increasingly detached from national borders and valued for their 'autonomous symbolic character' independently from the products for which they are used. ${ }^{2}$ Although countries in the past allowed for a range of measures under civil and competition law, the exceptional character of such protection led to demands for more immediate regulation of well-known marks as part of trade mark law. ${ }^{3}$

The international literature on well-known trade marks and intellectual property rights in developing countries often focuses on the concerns of foreign investors, who are seeking recognition of their well-known trade marks in newly emerging markets. ${ }^{4}$ In the past, the reception of well-known trade marks in the business environment of developing countries has not always been a straightforward matter. Local imitators often have the advantage of being earlier on the market, and imitative use of foreign well-known trade marks has been a thriving business. ${ }^{5}$ As a consequence, developing countries have been pressed by foreign trading partners to rectify the situation and to improve the protection of well-known marks.

The required protection of well-known marks at the international level runs into difficulties against two fundamental principles of trade mark law. First, as with any other form of intellectual property rights, the protective scope of trade marks is in principle limited by the geographical territory in which the trade mark is registered. ${ }^{6}$ Secondly, while some protection for internationally well-

${ }^{1}$ Annette Kur, 'Well-Known Marks, Highly Renowned Marks and Marks Having a (High) Reputation - What's It All About?' (1992) International Review of Industrial Property and Copyright Law 218, 218.

2 Ibid 221; Frederick W Mostert, 'Well-Known and Famous Marks: Is Harmony Possible in the Global Village?' (1996) 86 Trademark Reporter 103, 103-7.

${ }^{3}$ Kur, above n 1, 221-2.

${ }^{4}$ See, for example, Christoph Antons, 'The Recognition and Protection of Well-Known Trade Marks in Indonesia' (2008) 3(3) Journal of Intellectual Property Law \& Practice 185.

${ }^{5}$ Mostert, above n 2, 104-6.

${ }^{6}$ Christopher Heath, 'Protection of Well-Known Marks and Prevention of Trade Mark Piracy' in Christopher Heath and Kung-Chung Liu (eds), The Protection of Well-Known Marks in Asia (Kluwer Law International, 2000) 1. 
known marks was introduced in article 6bis of the Paris Convention for the Protection of Industrial Property, ${ }^{7}$ the protection applied only to goods identical with or similar to the ones for which the trade mark was registered and used $^{8}$ - a principle known as the specialty principle. In addition, article 10bis(3) of the Paris Convention prohibited more generally 'all acts of such a nature as to create confusion by any means whatever with the establishment, the goods, or the industrial or commercial activities, of a competitor'. ${ }^{9}$ Article 6bis prohibited the use of

a trade mark which constitutes a reproduction, an imitation, or a translation, liable to create confusion, of a mark considered by the competent authority of the country of registration or use to be well known in that country.

A generous period of five years to request cancellation of such marks was set, with no time limits at all for requests to cancel or prohibit the use of marks registered or used in bad faith.

The WTO Agreement on Trade-related Aspects of Intellectual Property Rights $^{10}$ (TRIPS) introduced important extensions of the principles enshrined in the Paris Convention. Article 16(1) of TRIPS, while applying only to registered marks and maintaining the specialty principle, added a presumption of likelihood of consumer confusion, where identical signs are used for identical goods or services. For well-known marks, article 16(2) of TRIPS provides that article 6bis of TRIPS shall no longer apply only to goods, but, mutatis mutandis, also to services. Article 16(2) also provides some interpretative standards to decide whether a trade mark is in fact well-known. Relevant is 'knowledge of the trademark in the relevant sector of the public' and that includes knowledge at the national level within the WTO member state 'which has been obtained as a result of the promotion of the trademark'.

To clarify the issue further, World Intellectual Property Organization (WIPO) members in 1999 adopted the Joint Recommendation Concerning Provisions

\footnotetext{
${ }^{7}$ Opened for signature 14 July 1967, 828 UNTS 305 (entered into force 20 March, 1883) ('Paris Convention').

${ }^{8}$ Heath, above n 6, 4.

${ }^{9}$ Daniel Gervais, The TRIPS Agreement: Drafting History and Analysis (Thomson Reuters, $3^{\text {rd }}$ ed, 2008) 274.

${ }^{10}$ Marrakesh Agreement Establishing the World Trade Organization, opened for signature 15 April 1994, 1867 UNTS 3 (entered into force 1 January 1995), annex 1C (Agreement on TradeRelated Aspects of Intellectual Property Rights) 1867 UNTS 299 (entered into force 1 January 1995) (TRIPS).
} 
on the Protection of Well-known Marks. ${ }^{11}$ Article 2(2) of the Joint Recommendation provides as examples of relevant sectors of the public the following:

(i) actual and/or potential consumers of the type of goods and/or services to which the mark applies;

(ii) persons involved in channels of distribution of the type of goods and/or services to which the mark applies;

(iii) business circles dealing with the type of goods and/or services to which the mark applies.

A WTO member state may further determine that a mark is a well-known mark, even if the mark is not well known or known in any relevant sectors of the public: article $2(2)(\mathrm{d})$. According to an accompanying note to this provision, it is meant to clarify that the preceding provisions are minimum standards that a member state may exceed. In such cases, the member state may require, however, that the mark be well known in one or more jurisdictions other than the member state: article 2(3)(b). Not required according to article 2(3)(a) shall be the following:

(i) that the mark has been used in, or that the mark has been registered or that an application for registration of the mark has been filed in or in respect of, the Member State;

(ii) that the mark is well known in, or that the mark has been registered or that an application for registration of the mark has been filed in or in respect of, the Member State;

(iii) that the mark is well known by the public at large in the Member State.

The principles of article 16(2) of TRIPS and the Joint Recommendations constitute a considerable expansion of the protection of well-known marks in comparison to article 6bis of the Paris Convention, which still requires that a mark be well-known locally. Article 6bis also did not comment on the question

11 Joint Recommendation Concerning Provisions on the Protection of Well-Known Marks, adopted by the Assembly of the Paris Union for the Protection of Industrial Property and the General Assembly of the World Intellectual Property Organization (WIPO) at the Thirty-Fourth Series of Meetings of the Assemblies of the Member States of WIPO, September 20-29, 1999, WIPO Document 833(E). 
of local use, ${ }^{12}$ which promptly became a requirement in many countries. ${ }^{13} \mathrm{~A}$ further extension of well-known marks protection comes in article 16(3) of TRIPS, which overcomes the limitation of the specialty principle and provides that article 6bis of the Paris Convention shall apply, mutatis mutandis, also to goods or services not similar to those in respect of which a trade mark is registered, "provided that use of that trade mark in relation to those goods or services would indicate a connection between those goods or services and the owner of the registered trade mark' and provided that the owners' interests are likely to be damaged by such use. It is pointed out that article 16(3), in contrast to article 16(2) of TRIPS, does not focus on confusion of the public, but protects the reputation of the well-known mark ${ }^{14}$ against dilution. ${ }^{15}$ While it is wider in this sense, it is important to bear in mind that it applies only to registered trade marks.

The increasing protection of well-known trade marks is an important issue for developing countries, as is evidenced by trade pressures from industrialised nations to recognise them. ${ }^{16}$ An important connection exists between the recognition of well-known marks and market dominance in certain sectors of the economy. Depending on how the criteria for well-known marks are defined, they may be difficult to fulfil for small and medium sized companies, which produce products popular at a local level and cannot point to the widespread international marketing that is often required from marks regarded as 'wellknown'. Local companies trying to gain market share in competition with wellestablished foreign brands may be at a disadvantage, because of a lack of sophisticated marketing techniques. Local products in many developing markets often have, rightly or wrongly, a reputation for being of inferior standard to those from industrialised countries in the European Union, the United States or Japan. In addition, there is the status factor of a consumer being able to afford an expensive foreign brand, which explains the continuing popularity of textile and other products with fake brand names. Finally, some consumers may simply derive pleasure from wearing the status symbols from far away countries, even if they are well aware that the products are fake and of inferior quality to the originals.

12 UNCTAD-ICTSD, Resource Book on TRIPS and Development (Cambridge University Press, 2005) 239-40; Gervais, above n 9, 276-7.

${ }^{13}$ For example in Indonesia until the reform of the Trade Marks Act in 1992 (Law No 19 of August 28, 1992 on Trade Marks); see Christoph Antons, Intellectual Property Law in Indonesia (Kluwer Law International, 2000) 204-6.

${ }^{14}$ UNCTAD-ICTSD, above n 12, 240-1.

${ }^{15}$ Gervais, above n 9, 277.

${ }^{16}$ Mostert, above n 2, 105-6. 
Companies owning such international brands are struggling to prevent such misuse of their symbols, which is particularly frequent among lower income earners in developing countries, while higher income earners in such countries will go to great lengths to acquire 'the real thing'. This has triggered the widespread 'trade mark squatting' phenomenon, in which locals register the well-known marks of companies, which have not yet extended their operation to the local market. Thus, rather than competing with foreign brands by establishing their own to enhance the reputation of their products, many enterprises instead try to profit from the established reputation of others. In this sense, preventing trade mark squatting should be a government priority and should help to strengthen the local economy. At the same time, however, it is important that honest concurrent use is respected. Not all use of foreign symbolism should be immediately associated with the 'trade mark squatting' phenomenon or pre-judged as indicating bad faith.

The UNCTAD-ICTSD Resource Book on TRIPS and Development takes note of the considerable extension of the protection of well-known marks and finds that ' $[\mathrm{t}]$ here is a risk that defining "well known" in terms of the relevant sector of the public will lead to a proliferation of well-known marks'. ${ }^{17}$ This article inquires into the extent to which that prediction is borne out by the evidence in two large developing countries, China and Indonesia. The analysis of wellknown marks in Asian developing countries often focuses on the degree to which the enhanced protection is implemented and enforced, and how this will impact on foreign investors and their intellectual property. ${ }^{18}$ While these are important questions, it is also important to see the local side of the coin, namely how the enhanced protection is made use of, and its impact on local companies. Given the wide scope of the protection of potentially many different types of products by the registration of well-known marks, and the monopolisation of the associated symbols, the identification of a trade mark as 'well-known' should be the exception rather than the norm. ${ }^{19}$ However, analysis reveals that, in both countries under consideration, there is often a lack of certainty about the principles that are to be applied.

Presenting a nuanced picture of trade mark protection in Asian developing countries also requires an analysis of the history of local well-known marks, and how and to what extent local companies participate in the system. This analysis is to be found in the following Part, starting with Indonesia. This will be followed by an analysis of the law reform in that country in the first few

\footnotetext{
${ }^{17}$ UNCTAD-ICTSD, above n 12, 240-1.

${ }^{18}$ See, for example, Antons, 'The Recognition and Protection of Well-Known Trade Marks', above $\mathrm{n} 4$.

${ }^{19}$ Heath, above n 6, 9 .
} 
decades after independence and following the TRIPS Agreement. A similar structure will then be followed for China, initially looking at the development of the trade mark system and the history of well-known marks. Parts V and VI will examine the impact of foreign investment and China's international obligations as well as the efforts by local companies to achieve recognition of their well-known marks. This will be followed by a conclusion.

\section{THE HISTORY OF LOCALLY WELL-KNOWN MARKS IN INDONESIA}

In contrast to the position in countries that have had a steady process of industrialisation and a gradual build-up of domestic brands, the developments in post-colonial societies can appear at times abrupt, distorted and full of conflict. This is especially the case if the decolonisation process has included a violent struggle for independence and the subsequent takeover of colonial businesses by newly independent governments, newly incorporated local companies, or even the army. Indonesia is a good example of a country that has had a difficult historical process of decolonisation which left a feeling of distrust and ambivalence towards the departing colonial power and the institutions it left behind.

Over a period of over four hundred years, parts of Indonesia were governed as a colony at first by the Portuguese, then by the Dutch East India Company or VOC (Vereenigde Oost-Indische Compagnie) and finally, with a brief British interregnum during the Napoleonic wars, by the government of the Netherlands East Indies. ${ }^{20}$ As did many other colonial powers, the Dutch governed their colony by using a pluralist legal regime that maintained different rules for different parts of the population, resulting in largely separate spheres of lives with different economic roles and opportunities. ${ }^{21}$ Over time, a complicated system developed, in which Dutch law applied to Europeans and to people from countries with what were regarded as similar legal systems. Predominantly Dutch commercial law applied to the so-called 'Foreign Orientals', Chinese, Arab, Indian and other Asian migrants with permanent residence in the colony; and predominantly Islamic law and traditional customary law (adat) applied to

\footnotetext{
${ }^{20}$ For a detailed history see M C Ricklefs, A History of Modern Indonesia Since c 1200 (Stanford University Press, $3^{\text {rd }}$ ed, 2001).

${ }^{21}$ Christoph Antons, 'Ethnicity, Law and Development in Southeast Asia', in Frans Hüsken and Dick van der Meij (eds), Reading Asia: New Research in Asian Studies (Curzon Press, 2001) 3.
} 
the local Indonesian population. An 'intergroup law' (intergentiel recht) was applied that regulated the relationships across the legal and ethnic boundaries. ${ }^{22}$

Many important laws, including a civil and commercial code and a civil procedural code, were introduced in 1848 . The first provision against the abuse of legally protected seals, stamps and trade marks was included in the Criminal Code in $1871 .{ }^{23}$ A complete Trade Marks Act was introduced in 1885, after the Netherlands had signed the Paris Convention in $1883 .{ }^{24} \mathrm{~A}$ further Act followed in 1893 after the conclusion of the Madrid Agreement concerning the International Registration of Marks..$^{25}$ The final Dutch colonial law regulating the field was the Reglement Industrieele Eigendom of 1912. ${ }^{26}$

The structure of the colonial legal system indicates, and the available case law from this period confirms, that these laws were mainly relevant for the 'European' and 'Foreign Oriental' parts of the population. ${ }^{27}$ While Dutch trading houses controlled international trade, Chinese, Indian and Arab traders and traders from elsewhere in Asia played an important role in the domestic trade of the interior. ${ }^{28}$ Their access to Dutch commercial law and their role in the colonial economy meant that they also had easier access to capital than Indonesians classified by the colonial system as 'natives', although the Indonesian elite had access to colonial law via processes of the intergentiel recht called gelijkstelling (equalisation) and vrijwillige onderwerping (voluntary submission to the Dutch law). Nevertheless, access of Indonesians to the legal system remained exceptional and discretionary, whereas it was a 'right' for 'foreign Orientals', at least as far as commercial law was concerned. Locally born 'foreign Orientals' were also often in a better position to identify what products would suit the local market than the Europeans.

\footnotetext{
${ }^{22}$ Sudargo Gautama, Hukum Antargolongan (Ichtiar Baru Van Hoeve, 1993); Sudargo Gautama and Robert N Hornick, An Introduction to Indonesian Law: Unity in Diversity (Penerbit Alumni, 1983) 1-22.

${ }^{23}$ Wetboek van Strafregt voor Nederlandsch-Indië, Staatsblad van Nederlandsch-Indië, No 55, 1866 , art 89.

${ }^{24}$ Staatsblad van Nederlandsch-Indië, No 109, 1885.

${ }^{25}$ Staatsblad van Nederlandsch-Indië, No 305, 1893.

${ }^{26}$ Staatsblad van Nederlandsch-Indië, No 545, 1912.

${ }^{27}$ See the cases of LAVENOR/LAVECO, Raad van Justitie Batavia of 17 April 1935 (1937) 143 Indisch Tijdschrift van het Recht 74-5; 'LAMPOE BATTERIJ', Hooggerechtshof van Nederlandsch-Indië of 24 October 1935 (1937) 143 Indisch Tijdschrift van het Recht 38; 'PO PO/HO HO', Raad van Justitie Batavia of 23 December 1936 (1939) 145 Indisch Tijdschrift van het Recht 93; 'LOLLYPOP', Raad van Justitie Batavia of 7 April 1937 (1941) 147 Indisch Tijdschrift van het Recht 775-6.

${ }^{28}$ Richard Robison, Indonesia: The Rise of Capital (Allen \& Unwin, 1986).
} 
It is hardly surprising then that many very successful brands during the late colonial period, especially those that were used for local products and met the taste of the Indonesian majority of the population, were established by 'foreign Orientals'. Excellent examples are brands for coffee, clove cigarettes (kretek), batik textiles and traditional medicine and herbal remedies (jamu). The power of advertising can be seen, for example, from the recent history of Indonesia's most famous coffee brand KAPAL API (steamship). The Kapal Api company was founded in 1927 by a migrant from Fujian province in China, who named his coffee after the steamship by which he arrived in the Netherlands East Indies. At that stage, and indeed until the 1970s, there was little branding of coffee, which was normally sold in small packets wrapped in newspaper at local markets. ${ }^{29}$ The son of the company founder changed this with an advertising campaign that catapulted the company from a small Surabaya based coffee roaster to the largest coffee company in Indonesia by the mid-1980s. Another Chinese family company from Surabaya is behind the SINGA (Lion) brand, which goes back to 1928. Unlike the KAPAL API brand, the SINGA brand was used from the beginning. ${ }^{30}$ Other well-known coffee brands have a similar history of Chinese family ownership going back to the colonial period, with the oldest of them founded in $1878 .^{31}$

Unlike coffee, which was appreciated by all people in the colony, the Indonesian clove flavoured cigarette kretek was from the beginning a product made by Indonesians predominantly for Indonesian consumers who preferred these to the rokok putih, the ordinary unflavoured cigarettes smoked by the Europeans. In fact, so strong has the distinction between these two products always been, that the District Court of Central Jakarta in a decision in 1973 declined to find a similarity between the cigarette brands Fortuna and Fortune, among other reasons because one was used for kretek and the other for ordinary cigarettes. $^{32}$ The commercial production of klobot kretek, kretek wrapped in cornhusk, began in the early $20^{\text {th }}$ century in a Javanese owned family company. Its owner was the son of a village head near Kudus and he began to market his kretek under the brand name BAL TIGA (Three Balls). The fortune of this

29 The history of KAPAL API is summarised in Gabriella Teggia and Mark Hanusz, A Cup of Java (Equinox Publishing, 2003).

${ }^{30}$ Ibid 82.

${ }^{31}$ For the history of TEK SUN HO in Jakarta and AROMA in Bandung, see Teggia and Hanusz, above $n 29,75-6,83$.

${ }^{32}$ District Court of Central Jakarta of 13 March 1973, 333/1972 G, FORTUNA, in: Direktorat Jenderal Hukum dan Perundang-undangan Departemen Kehakiman, Keputusan-keputusan Pengadilan tentang Sengketa Merek, (Direktorat Jenderal Hukum dan Perundang-undangan, 1981) 92. See also Antons, above n 13, 230. 
company declined after World War II due to a mixture of family feuds, the economic effects of the Japanese occupation and counterfeits by competitors. ${ }^{33}$

Gradually, the production of kretek became mechanised and the market dominated by larger companies with access to domestic industry development loans made by the Suharto government in particular. Of the most successful ones, the Sampoerna company with its original flagship brand DJI SAM SOE (2-3-4) and the Bentoel company (cassava root) with its flagship trade mark of the same name are again Chinese owned companies with roots in the colonial period, while the Djarum (needle) company and the Gudang Garam (salt warehouse) company, using their trade marks of the same names, were founded in the 1950s. What is striking about these trade marks is, first of all, their simplicity. ${ }^{34}$ Like other local trade marks with a long history, they were designed at a time when sophisticated marketing techniques were not yet available, and even the printing of labels was still frequently done with a hand press. ${ }^{35}$ They had to appeal to predominantly local consumers, who in rural areas at that time could well still be illiterate. ${ }^{36}$ If many of them appear to be odd choices from the perspective of contemporary marketing practices, this has to do with the role of mysticism in Indonesian businesses. Business owners often use symbols that a practitioner of Javanese mysticism or a spiritual adviser recommends as most likely to bring good fortune. ${ }^{37}$ Alternatively, they may use as their trade marks objects that appear to them in dreams or meditation. In other words, while trade marks are of course meant to attract the attention of consumers and distinguish their goods from the goods of other traders, they are also good luck charms for their owners. DJI SAM SOE, for example, is the lucky number of the owner in the Hokkien language. It adds up to nine, has nine letters and nine stars on the packaging and is owned by the Sampoerna company, again with nine letters. This company has also marketed other products with such lucky number combinations. BENTOEL was chosen by its owner after a bentul vendor appeared to him in a dream when he spent a night on a sacred mountain in East Java at the tomb of a sixteenth-century

\footnotetext{
${ }^{33}$ Mark Hanusz, Kretek: The Culture and Heritage of Indonesia's Clove Cigarettes (Equinox Publishing, 2003) 32-49.

${ }^{34}$ Rudy Badil, Kretek Jawa: Gaya Hidup, Lintas Budaya (Kepustakaan Populer Gramedia, 2011) 97.

${ }^{35}$ Ibid 100.

${ }^{36}$ The Indonesian writer Pramoedya Ananta Toer mentions that at the end of the Dutch colonial period less than four per cent of the country's population could read or write, as quoted in Hanusz, above n 33, 3 .

${ }^{37}$ Badil, above n 34, 102.
} 
ascetic. ${ }^{38}$ Similarly, GUDANG GARAM referred to an old salt warehouse, which appeared to its owner in a dream regarded by the owner as symbolic. ${ }^{39}$ Yet the clearest indication of the role of a trade mark as 'good luck charm' for English speakers is in the case of WISMILAK, the Indonesian adaptation of 'Wish me luck'.

A recent case involving the use of 'good luck' symbolism involved the furniture manufacturer Ikea and the local IKEMA brand used for tiles. In a revision of earlier decisions, Angsa Daya, the company manufacturing IKEMA, persuaded the Supreme Court that the meaning of IKEMA in Mandarin Chinese was 'as fast as a horse'. It was chosen because 'horse' was the zodiac sign of one of the directors and also because it was the acronym of 'Industri Keramik Milik Angsa Daya' (a ceramic business owned by Angsa Daya). ${ }^{40}$

Such acceptance of trade marks derived from the Chinese language stands in marked contrast to the policy of much of the 'New Order' period. The attempted coup of 1965 that led to the downfall of the Sukarno government and the establishment of Suharto's 'New Order' government was blamed on the Indonesian Communist Party, which allegedly had backing from mainland China. Subsequently, Indonesians of Chinese descent were asked to assimilate and to change their names to Indonesian names, and Chinese language schools were closed down. Trade marks that used Chinese language names or symbols, or originated in China, could be excluded from registration on the basis that such marks contravened public order. ${ }^{41}$ Diplomatic relations between Indonesia and the People's Republic of China were finally restored in 1990, and Chinese language trade marks could finally be registered again in the same way as any other trade mark in Indonesia. ${ }^{42}$

An added advantage of such 'good luck charm' marks from a trade mark law perspective is sometimes their relatively strong distinctive character. This, however, is not always the case, because many rely on a limited repertoire of

\footnotetext{
${ }^{38}$ Badil, above n 34, 107; Hanusz, above n 33, 130. Bentul is the root of the cassava plant. BENTOEL is a rendering of that word using Dutch spelling.

${ }^{39}$ Badil, above n 34, 107.

${ }^{40}$ Supreme Court No 165PK/Pdt.Sus/2012 of 18 January 2013.

${ }^{41}$ See, for example, District Court of Central Jakarta No 33/1972 G of 3 October 1973, FLYING WHEEL, in Direktorat Jenderal Hukum dan Perundang-undangan Departemen Kehakiman, Keputusan-Keputusan Pengadilan tentang Sengketa Merek 1971-1977 (Direktorat Jenderal Hukum dan Perundang-undangan Departemen Kehakiman, 1981) 117.

${ }^{42}$ Christoph Antons, 'From Magic Charms to Symbols of Wealth: Well-Known Trade Marks in Indonesia' in Andrew T Kenyon, Ng-Loy Wee Loon and Megan Richardson (eds), The Law of Reputation and Brands in the Asia Pacific (Cambridge University Press, 2012) 142, 149-50.
} 
good luck numbers. ${ }^{43}$ Lack of distinctiveness can also become a problem because of the other feature of Indonesian trade marks, namely their simplicity, designed as they are to appeal to a local and rural population. As mentioned above, BAL TIGA was a frequently counterfeited trade mark for kretek, a fact that contributed to its ultimate demise. Badil reports other examples of cases in which competitors have attempted to profit from the reputation of a well-known mark. Sampoerna's '3-4-2' trade mark, for example, was used by a competitor on Java in its Javanese translation SAMSUJI; a competitor of GUDANG GARAM began to market GUDANG BARU (new warehouse); and the trade mark DJARUM (needle), which used an image of a gramophone needle on its label, was promptly copied in the trade mark DJARUM GRAMOPHON. ${ }^{44}$ Since Indonesians are relatively reluctant to go to court, ${ }^{45}$ many of these disputes were presumably settled out of court. Occasionally, however, they became the subject of trade mark disputes. Rather than focusing on the impression of the mark as a whole, and the actual distinctiveness of the word 'premium', for example, the Special District Court of Jakarta found substantive similarity between Bentoel's new product line BENTOEL PREMIUM and an earlier registered cigarette trade mark PREMIUM. ${ }^{46}$

Examples of more recent successful trade marks consisting of simple words and symbols include the trade mark SUPERMI for instant noodles, TEH BOTOL (tea bottle) for bottled tea and the word AQUA for bottled water. The owners of both SUPERMI and AQUA had to battle competitors in court that were seeking cancellation of these marks on the basis of lack of distinctiveness. In the case of SUPERMI, a combination of the word 'super' and the short form of the Indonesian word for 'noodle' (bakmi), the District Court of Central Jakarta found the trade mark sufficiently distinctive because of the characteristic manner in which the word was written on the label. ${ }^{47}$ In the case of AQUA, the Indonesian Supreme Court decided in favour of the company on the basis of acquired distinctiveness. ${ }^{48}$ Another recent case involving spa and beauty

\footnotetext{
${ }^{43}$ See Badil, above $\mathrm{n} 34$, for the preference for combinations adding up to ' 3 ' and ' 9 '.

${ }^{44}$ Ibid $110-11$.

${ }^{45}$ Antons, above n 13, 310-11.

${ }^{46}$ Special District Court of Jakarta 2/1970 G of 1 April 1970. See the discussion of this case in Antons, above n 13, 231-2.

${ }^{47}$ District Court of Central Jakarta No 904/1070 of 30 January 1971, in Sudargo Gautama and Rizawanto Winata, Himpunan Keputusan Merek Dagang (Alumni, 1987) 57-62. See also the discussion of the case in Sudargo Gautama and Rizawanto Winata, Pembaharuan Hukum Merek Indonesia Dalam Rangka WTO, TRIPS, 1997 (Citra Aditya Bakti, 1997) 36-7 and in Antons, above n 13, 224-5.

48 Supreme Court No 980K/Pdt/1990 of 30 March 1992, AQUA/AQUARIA, in Sudargo Gautama, Himpunan Jurisprudensi Indonesia Yang Penting Untuk Praktek Sehari-hari (Landmark Decisions) Berikut Komentar Jilid 8 (Citra Aditya Bakti, 1993) vol 5, 36, 40-2.
} 
products and illustrating the same principle concerned the trade mark KAYU MANIS (sandalwood), an important ingredient in such beauty products. ${ }^{49}$

Positioned between some of the more strongly distinctive 'good luck charm' marks and the very simple marks referring to the early industrial products of recent decades, are those brands that use Indonesian craft objects and mystical characters from the wayang, Indonesia's shadow play, based on epic stories such as the Mahabharata or the Ramayana. Such symbolism is also popular for typical Indonesian products. It has been used, for example, for kretek $^{50}$ and, in particular, in the batik industry. One of the larger batik companies uses the very popular local shadow play character SEMAR as its trade mark, while another large batik producer uses the words BATIK KERIS, together with the distinctive Javanese dagger, which is often associated with mystical qualities, as its trade mark. ${ }^{51}$

The history of such iconic brands in Indonesia shows that they are still largely used for typical Indonesian products and are rarely acquiring the symbolism for a wide range of different products that is often associated with global brands. Many of them are, therefore, strong brands for their particular product range. Perhaps for that reason, they rarely have to be defended in court. On the other hand, relatively simple marks selected in the early days of trade mark protection, did face widespread imitation. Some of those were successfully defended in the courts; others, such as the kretek brand BAL TIGA, went out of business.

\section{FOREIGN INVESTMENT, TRIPS AND THE REFORM OF THE INDONESIAN TRADE MARK SYSTEM AFTER WORLD WAR II}

Trade mark law protection had a shaky start in independent Indonesia. Indonesia achieved its independence after an armed struggle against the returning Dutch colonial power that lasted from 1945 to 1949. As the fighting parties controlled different parts of the country, it meant that two authorities temporarily regulated the field of intellectual property. Very little is known about what efforts, if any, the young government of the Republic of Indonesia made in this field during this period. However, reference is made in a trade mark case of 1971 to an independent 'Office for Industrial Property' of the

\footnotetext{
${ }^{49}$ Supreme Court No 837K/Pdt.Sus/2012 of 14 March 2013, KAYU MANIS.

${ }^{50}$ The kretek manufacturer Nojorono used the wayang character Minak Djinggo; see Hanusz, above $\mathrm{n} 33,126$.

${ }^{51}$ Antons, above n 42, 147.
} 
Republic of Indonesia in Surakarta (Solo) during the independence struggle. ${ }^{52}$ Meanwhile, the Netherlands continued to accede to international conventions on behalf of its colonies. After independence was finally granted in 1949, this created some confusion about the continuing validity of such accessions, particularly if they occurred in the interim period between the official declaration of Indonesian independence in 1945 and its recognition by the departing colonial power in 1949. This concerned, in particular, the 1948 Dutch accession to the London Revision of the Paris Convention, the Madrid Agreement for the Repression of False or Deceptive Indications of Source on Goods, and the Hague Agreement concerning the International Registration of Industrial Designs. All of these accessions, as well as to the 1947 Neuchâtel Agreement for the Preservation or Restoration of Rights of Industrial Property Affected by the Second World War, were published in 1948 and 1949 in the official state gazette of the colony, the Staatsblad van Nederlandsch-Indië, renamed in 1949 as the Staatsblad van Indonesië. ${ }^{53}$

Although the Indonesian government declared on various occasions that the new republic was bound by the international agreements concluded by the Dutch ${ }^{54}$ overly nationalistic Indonesian courts during the 1970 s occasionally denied the applicability of the Paris Convention, because it was not signed and ratified by Indonesia itself, ${ }^{55}$ or regarded it as subsidiary to national law. ${ }^{56}$ Regarding national law, the colonial era Reglement Industrieele Eigendom of 1912 initially remained in force on the basis of a transitional provision in the Constitution that provided that all enacted laws and institutions would stay in force until their replacement by new Acts and institutions created in accordance

\footnotetext{
${ }^{52}$ Supreme Court, 580K/Sip/1970 of 27 March 1971, KOERMA in Direktorat Jenderal Hukum dan Perundang-undangan Departemen Kehakiman, Himpunan Keputusan Mahkamah Agung, above $\mathrm{n} 41,2$.

${ }^{53}$ Staatsblad van Nederlandsch-Indië, No 134, 1948; Staatsblad van Nederlandsch-Indië, No 49, 1949. See also Antons, above n 13, 44-5.

54 The Indonesian Foreign Ministry in 1950 sent a declaration to the Swiss Federal Council confirming that Indonesia was bound by the London version of the Paris Convention and several other agreements, see 'Circulaire du Conseil Fédéral Suisse (Département Politique Fédéral) concernant la situation de la République des États-Unis d'Indonésie à l'égard de certains actes de l'Union du 24 Novembre 1950' (1950) 66 La Propriété Industrielle 222. Indonesia also signed the Stockholm Act of the Paris Convention with the exception of arts 1-12 in 1979 and ratified it in 1997.

${ }^{55}$ District Court of Central Jakarta, No 521/1971 G and No 53/1972 G of 30 March 1972, TANCHO in Sudargo Gautama and Rizawanto Winata, Himpunan Keputusan Merek Dagang, above $\mathrm{n} 47,35$.

${ }^{56}$ Special District Court of Jakarta No 336/1972 G of 13 December 1973, MISS PARIS in Direktorat Jenderal Hukum dan Perundang-undangan, Keputusan Pengadilan 1971-1977, above $\mathrm{n} 41,101$.
} 
with the Constitution. ${ }^{57}$ The colonial law was finally replaced in 1961 by Indonesia's own legislation on the subject matter. ${ }^{58}$ However, because it largely adopted the provisions of the previous law, including allocating the rights on the basis of first use rather than registration, it remained common for lawyers and courts until the 1980s to quote from academic literature and court decisions from the colonial period. ${ }^{59}$

During its first two decades, the new republic was preoccupied with concerns about a return of the Dutch colonial power and, indeed, about activities of other colonial powers in the region, such as the British in neighbouring Malaysia. ${ }^{60}$ In the economic sphere, this translated into nationalist economic policies and a striving towards self-sufficiency that Indonesia's first President Sukarno famously expressed in his berdikari slogan.$^{61}$ This left little scope for foreign capital. In 1957 the remaining Dutch companies were placed under military supervision and in 1958 expropriated. Robison has pointed to the fact that this expropriation 'involved the transfer of ownership of $90 \%$ of plantation output, $60 \%$ of foreign trade, some 246 factories and mining enterprises, plus banks, shipping and a variety of service industries ${ }^{9}{ }^{62}$ One of the current Indonesian companies whose origins go back to this period is the Bintang brewery. It resulted from a takeover of the Dutch East Indies branch of Heineken. The now famous and widely popular BINTANG trade mark was created to replace the HEINEKEN brand. It was renamed BIR BINTANG BARU (the new BINTANG beer) after Heineken returned in 1967 as a joint venture partner. ${ }^{63}$

Policies towards foreign capital and foreign investment changed from the mid1960s onwards after the military-backed 'New Order' government of Indonesia's second president, President Suharto, came into power. Indonesia's Foreign Capital Investment Law of 1967 re-opened the country to foreign investors by offering tax incentives and assurances against nationalisation or

\footnotetext{
${ }^{57}$ Sudargo Gautama, 'Legal Developments in Independent Indonesia (1945-1970)' (December 1970) Lawasia 157.

${ }^{58}$ Undang-Undang No. 21 Tahun 1961 Tentang Merek Perusahaan dan Merek Perniagaan, Lembaran Negara Republik Indonesia 1961 No 290.

${ }^{59}$ For examples see Antons, above n 13, 205 n 30.

${ }^{60}$ Michael Leifer, 'The Changing Temper of Indonesian Nationalism' in Michael Leifer (ed), Asian Nationalism (Routledge, 2000) 155.

${ }^{61}$ Berdikari is an acronym for berdiri di atas kaki sendiri (standing on one's own feet). On this period of Indonesian economic history see Hal Hill, The Indonesian Economy Since 1966: Southeast Asia's Emerging Giant (Cambridge University Press, 1996) 1-3.

${ }^{62}$ Richard Robison, above n 28, 72.

63 The trade mark image can be seen at: <www.birbintang.co.id/en/inside_beer_history. htm; www.heinekeninternational.com/content/live/files/downloads/History\%20of\%20Hein eken.pdf>. See Antons, above n 42, 143-4.
} 
foreign exchange restrictions. ${ }^{64}$ In the decades since then, Indonesia has remained an attractive destination for foreign investors, although policies have shifted between very open and more restrictive regulatory regimes, depending on the availability of other sources of revenue, and the influence of different visions of economic policy-making in government and administration. ${ }^{65}$ In any case, most of the foreign well-known brands arrived during the more liberal foreign investment climate from the late 1960s onwards. Frequently their owners were surprised to find that their trade mark was already registered and/or well-represented on the Indonesian market. This was due mainly to two different types of business. On the one hand there were businesses that had begun to use foreign symbols and words in the early years of the 'New Order' government, when consumers were rushing to taste unfamiliar Western style products that were produced locally. The old Indonesian Trade Marks Act of 1961 (Law No 21 of 1961) had nothing to say about well-known marks, there were no lists of such marks and, as explained earlier, the courts and the trade mark registration agencies were in most cases still unaware of Indonesia's obligations under the Paris Convention. One such company was the wellknown Surabaya ice cream manufacturer Campina, which was set up in 1972 and soon began to sell ice cream cones using the term CORNETTO.

At the international level, CORNETTO is one of the flagship brands of Unilever. In 2002, Unilever sued Campina in the Commercial Court of Central Jakarta. ${ }^{66}$ The plaintiff was seeking recognition for CORNETTO as a wellknown mark and for its exclusive rights to the trade mark and cancellation of the competing CAMPINA CORNETTO mark, because this mark was substantially identical with the plaintiff's mark and had been registered, it alleged, in bad faith. It was important for Unilever to base the argument on bad faith, because cancellation proceedings under Indonesian trade mark law are subject to a time bar of five years after registration. Campina had registered the mark in 1988, so the time bar had clearly been exceeded in this case. The Central Jakarta Commercial Court agreed that the time bar had to be ignored in this case,${ }^{67}$ but found in favour of the defendant on the substantive points. At the time the trade mark was registered, the Unilever CORNETTO brand was

\footnotetext{
${ }^{64}$ Christoph Antons, 'Japan as a Model? Comparing Law and Development in Japan, Singapore and Indonesia' in Christoph Antons (ed), Law and Development in East and Southeast Asia (Routledge Curzon, 2003) 216, 234.

${ }^{65}$ For a brief sketch, see ibid 231. For foreign investment in particular see Hill, above n 61, 768.

${ }^{66}$ Commercial Court of Central Jakarta No 29/Merek/2002/PN.Niaga.Jkt.Pst of 17 September 2002, CORNETTO in Tim Redaksi Tatanusa (eds), Himpunan Putusan-Putusan Pengadilan Niaga Dalam Perkara Merek (Jakarta: PT Tatanusa, 2004) vol 3, 203-41.

${ }^{67}$ See also Supreme Court No 762K/Pdt.Sus/2012 of 26 February 2013, PIAGET.
} 
not yet known in Indonesia, hence there was no possibility of confusion of consumers, and no bad faith by the defendant in attempting to confuse consumers.

The plaintiff had raised the cancellation claim pursuant to article 68 of the Trade Marks Act with reference to article 6(1)b of that Act. Article 6(1)b provides that an application for a trade mark registration has to be rejected if the mark is deceptively similar to or substantially identical with, a well-known mark owned by someone else and used for goods and/or services of the same kind. On the conditions that need to be fulfilled for a mark to be recognised as well known, the explanatory memorandum to the provision mentions the following: the general knowledge of the public about the mark in the relevant branch of trade; the reputation of the mark because of continuous and substantial promotion; investment in the trade mark in several countries; and proof of registration in several countries. ${ }^{68}$ The plaintiff showed registration and promotion of the trade mark in many countries, but the Central Jakarta Commercial Court found that this alone was insufficient. It was still important to ask to what extent a trade mark was known in the country prior to the registration by the defendant. ${ }^{69}$

The Indonesian Supreme Court overturned the decision on appeal. It relied on the influential textbook of Gautama and Winata ${ }^{70}$ to find that the criteria of promotion and registration in several countries constituted powerful evidence of the well-known character of the mark. Because the cancellation claim had to further overcome the obstacle of the five year time bar for such proceedings, the Supreme Court found that Campina had also acted in bad faith in registering the mark. The court came to this conclusion using the argument that bad faith was proven by the fact that Campina had not chosen another mark in the Indonesian language. ${ }^{71}$

While ignorance rather than bad faith could have been the reason for the registration of well-known marks in a few cases, the bad faith of the applicant is rather obvious in cases that involve a lucrative and longstanding 'trade in marks'. This term refers to the spotting overseas and registering at home of well-known marks by 'trade mark entrepreneurs' with the aim of selling the

\footnotetext{
${ }^{68}$ See Antons, above $\mathrm{n} 4,189$.

${ }^{69}$ Commercial Court of Central Jakarta No. 29/Merek/2002/PN.Niaga.Jkt.Pst. of 17 September 2002, CORNETTO, above n 66, 238.

${ }^{70}$ Gautama and Winata, Pembaharuan Hukum Merek Indonesia, above n 47, 57.

${ }^{71}$ Supreme Court No $022 \mathrm{~K} / \mathrm{N} / \mathrm{HaKI} / 2002$ of 20 December 2002, 'CORNETTO ' in Tim Redaksi Tatanusa (eds), Himpunan Putusan-Putusan Mahkamah Agung Dalam Perkara HaKI (Tatanusa, 2002) vol 2, 60.
} 
rights back to the original owners, once the business has expanded its operation to Indonesia. With the Indonesian market not having been particularly attractive prior to the economic opening up of the country in the late 1960s and early 1970s and the subsequent boom in foreign investment, it is hardly surprising that the 'trade mark entrepreneurs' had found a lucrative source of income for some time. They often held entire portfolios of foreign marks without any real intention to use the mark. Nevertheless, with the rights to a trade mark under the 1961 Trade Marks Act being determined by first use in the country, foreign right holders faced uncertain prospects in legal proceedings, as the first use requirement could be easily manipulated. Many decided that it was better to bite the bullet and buy their rights back. Indonesian media ${ }^{72}$ and practitioners in $\mathrm{Jakarta}^{73}$ reported prices between US\$10 000 and US\$100 000 for such arrangements in the early 1990s.

The system began to improve after the new trade mark legislation, enacted in 1992 and in force since 1993, shifted from the principle of first use to first registration as the basis of trade mark rights, and introduced well-known trade mark protection as part of the law. ${ }^{74}$ Further improvements came with the introduction of the current law of $2001^{75}$ and the shift of responsibility for intellectual property cases from the overburdened general District Courts (Pengadilan Negeri) to specialised Commercial Courts (Pengadilan Niaga) with exclusive responsibility for intellectual property and bankruptcy litigation. ${ }^{76}$ Subsequently, Indonesian courts developed three different lines of decision making for cases involving foreign and well-known trade marks. In some cases, the mere foreign character of the trade mark was found to be sufficient to establish bad faith, as it led consumers to think that the product was foreign made; there was no further need to decide on the well-known character of the mark. ${ }^{77}$ There are, however, in many cases perfectly legitimate

${ }^{72}$ Aries Margono, G Sugrahetty, Siti Nurbaiti and Indrawan, 'Menyapu Mafia Pedagang Merek', Tempo (Jakarta), 1 August 1992.

${ }^{73}$ Peter Rouse and Didi Dermawan, 'Indonesia: A Fresh Look at the Protection and Enforcement of Trade Marks, Part 2: Enforcement' (1991) 38 Trade Mark World 25.

${ }^{74}$ On the various stages in which this was achieved under the Trade Marks Act of 1992, see Antons, above n 4, 186-7.

${ }^{75}$ Law No 15 of 2001 concerning marks.

${ }^{76}$ For details see Christoph Antons, 'Specialised Intellectual Property Courts in Southeast Asia' in Annette Kur, Stefan Luginbühl and Eskil Waage (eds), ... und sie bewegt sich doch!' - Patent Law on the Move (Carl Heymanns Verlag, 2005) 287; Christoph Antons, 'Doing Business in Indonesia: Enforcement of Contracts in the General Courts and the Creation of a Specialized Commercial Court for Intellectual Property and Bankruptcy Cases' (Working paper AED-EAL2007-4, Attractivité Economique du Droit Programme international de recherches, 2007).

${ }^{77}$ See, for example, Commercial Court of Central Jakarta No 11/Merek/2001/PN.Niaga.Jkt.Pst of 26 March 2002, SANTA BARBARA POLO \& RACQUET CLUB in Tim Redaksi Tatanusa 
reasons for the use of a foreign symbol or name. In the absence of other compelling reasons to make a finding of bad faith, the use of the foreign symbolism of the trade mark as an indicator is often too simple.

In a second group of cases, the courts added the well-known character of the mark to considerations of bad faith. In assessing the well-known character of the mark, they applied the guiding criteria from the explanatory memorandum to article 6(1)b of the Trade Marks Act. A typical judgment is that concerning the Swiss watch brand AUDEMARS PIGUET, in which the trade mark was found to be well-known because of its promotion in approximately 60 countries and registration in many neighbouring countries. ${ }^{78}$

Finally, especially in those cases where the time bar for cancellation proceedings rendered reliance on the bad faith argument unnecessary, the Commercial Court developed the further approach of finding that article 6(1)b applied where the two trade marks were for goods of the same kind. Control over the use of the well-known mark for goods that are not of the same kind requires, according to article 6(2), a further implementing government regulation, but this regulation has never been issued. Hence, this has created a legal void (kekosongan hukum) that the court needed to fill by a direct application of article 16(3) of TRIPS. ${ }^{79}$ This approach was subsequently endorsed by the Supreme Court. ${ }^{80}$ The focus on promotion and registration in many countries, as indicators of the well-known nature of the mark, has recently

(ed), Himpunan Putusan-Putusan Pengadilan Niaga Dalam Perkara Merek (PT Tatanusa, 2002) vol 2, 1, 15; Commercial Court of Central Jakarta No 70/Merek/2003/PN.Niaga.Jkt.Pst of 18 December 2003, 'PIEN TZE HUANG' in Tim Redaksi Tatanusa (eds.), Himpunan Putusan-Putusan Pengadilan Niaga Dalam Perkara Merek, (Tatanusa, 2006) vol 7, 131, 147 (confirmed by the Supreme Court in No. 01K/N/HaKI/2004 of 21 November 2003, 'PIEN TZE HUANG', Tim Redaksi Tatanusa (eds.), Himpunan Putusan-Putusan Mahkamah Agung Dalam Perkara HaKI (Tatanusa, 2005) vol 5, 19, 31; Commercial Court of Central Jakarta No 033/Merek/2003/PN.Niaga.Jkt.Pst of 22 July 2003, FERRAGAMO in Tim Redaksi Tatanusa (eds.) Himpunan Putusan-Putusan Pengadilan Niaga Dalam Perkara Merek (Tatanusa, 2005) vol 5, 307.

${ }^{78}$ Commercial Court of Central Jakarta No 06/Merek/2001/PN.Niaga.Jkt.Pst of 27 February 2002, AUDEMARS PIGUET, in: Tim Redaksi Tatanusa (eds), Himpunan Putusan-Putusan Pengadilan Niaga Dalam Perkara Merek (Tatanusa, 2002) vol 1, 131. For other cases using this line of argument see Antons, above n 4, 189 n 26.

${ }^{79}$ On this basis, the cancellation of the trade mark MORGAN was ordered; see Commercial Court Central Jakarta No 09/Merek/2001/PN.Niaga.Jkt.Pst of 12 March 2002 in Tim Redaksi Tatanusa (eds), Himpunan vol 1, above n 78, 237.

${ }^{80}$ Supreme Court No 044K/N/HaKI/2003 of 24 March 2004, NOKIA in Tim Redaksi Tatanusa (eds), Himpunan Putusan-Putusan Mahkamah Agung Dalam Perekara HaKI (Tatanusa, 2004) vol 4, 265. See also, more recently, Supreme Court No 61K/Pdt.Sus-HKI/2013 of 22 August 2013, FOREVER 21; No 445K/Pdt.Sus/2012 of 24 September 2012, TEFLON. 
been confirmed in many more cases. ${ }^{81}$ In a 'further revision' (peninjauan kembali) in the case of the IKEA brand owner against the manufacturer of ceramic tiles using the trade mark IKEMA, however, the Supreme Court declined to rely on the legal void argument and to apply article 16(3) of TRIPS directly. The court pointed out that the lack of an implementing regulation in accordance with article 6(2) meant that article 6(1)b of the Trade Marks Act on well-known trade marks simply could not be implemented. ${ }^{82}$

In view of the fact that subsequent Supreme Court decisions endorsed the approach that has now been taken in the majority of cases ${ }^{83}$ the IKEA/IKEMA decision seems to represent a temporary aberration. ${ }^{84}$ Thus, the protection of well-known trade marks in Indonesia is by now firmly established and the cases indicate that the enhanced protection is claimed especially by foreign and multinational companies. Local companies are much less frequently involved in such cases, perhaps because they settle out of court. However, for small and medium sized enterprises (SMEs) marketing typical Indonesian products, criteria such as promotion and registration in many countries are often not relevant, or not relevant to the same extent, because their products may be popular in the huge Indonesian market, but not in other countries. ${ }^{85}$ Indonesia's iconic brands described in the previous section of this article, on the other hand, are exceptionally strong marks indicating the quality of their products and, as such, apparently well respected both among consumers and by competing businesses. ${ }^{86}$

\footnotetext{
${ }^{81}$ See, for example, Supreme Court No 476K/Pdt.Sus/2012 of 12 September 2012, MCM AND LOGO; No 590K/Pdt.Sus/2012, BIORE; No 610K/Pdt.Sus-HKI/2013 of 30 December 2013, WAVIN; No 762/K/pdt.Sus/2012 of 26 February 2013, PIAGET; No 138PK/Pdt.Sus/2011 of 14 December 2011, MALING; No 535K/Pdt.Sus/2009 of 8 January 2010, XANGO; No 679K/Pdt.Sus/2010 of 21 September 2011, ABSORTECH; No 485K/Pdt.Sus/2009 of 27 August 2009, KOYO; No 736K/Pdt.Sus/2009 of 24 November 2009, SUBWAY; No 710K/Pdt.Sus/2009 of 14 December 2009, CALIFORNIA SCENTS.

${ }^{82}$ Supreme Court No 165 PK/Pdt.Sus/2012 of 18 January 2013, 51-2.

83 Supreme Court No 610K/Pdt.Sus-HKI/2013 of 30 December 2013, WAVIN; No 762/K/pdt.Sus/2012 of 26 February 2013, PIAGET.

${ }^{84}$ See also 'Wilayah Abu-Abu Merek Terkenal: Perlu pengaturan lebih lanjut mengenai kriteria merek terkenal', hukumonline, 18 June 2013 <http://www.hukumonline.com/berita/ baca/lt51c015c8adb64/wilayah-abu-abu-merek-terkenal>.

85 'PP Merek Terkenal Harus Perhatikan Merek Lokal', hukumonline, 27 December 2004 <http://www.hukumonline.com/berita/baca/hol11897/pp-merek-terkenal-harus-perhatikanpemegang-merek-lokal>.

${ }^{86}$ Antons, above n 42, 154.
} 


\section{The Development of Trade Mark Protection and Well-Known Trade Marks in China}

In China there are two possible principal meanings for the term 'trade mark'. The first meaning of 'trade mark' is that it simply indicates the origin of a particular product with its maker. In this sense trade marks in China appear to have a very long history. ${ }^{87}$ Some believe that trade marks in this sense emerged as early as around $2698 \mathrm{BC},{ }^{88}$ when craftsmen put certain initials or special signs on their ceramics, tools or weapons. The second meaning of 'trade mark' is that it emphasises a 'mark' for a 'trade'. This second meaning probably appeared during a much later period, when there was a genuine commercial and trading environment in the Song Dynasty (960-1279), ${ }^{89}$ a dynasty well-known for its commerce and prosperity in general. Chinese scholars believe that the earliest trade mark can be traced back to the label WHITE RABBIT ${ }^{90}$ for fine needles in a shop in Jinan City, Shandong Province during this time. It was an era when commerce was thriving, when paper currency was developed, new markets emerged and the urban population increased. ${ }^{91}$ WHITE RABBIT was very much like a modern trade mark, consisting of a combination of both words and pictures, and indicating the manufacturer and the seller of the product. ${ }^{92} \mathrm{~A}$ copper plate of the WHITE RABBIT trade mark is kept in the History Museum of China. ${ }^{93}$

However, it was not until the end of the Qing Dynasty (1644-1911) that China implemented laws to protect trade marks. ${ }^{94}$ In 1904, in the last few years of the

${ }^{87}$ Giana M Eckhardt and Anders Bengtsson, 'A Brief History of Branding in China' (2010) 30 Journal of Macromarketing 210, 212-13.

${ }^{88}$ Ke Shao, 'Look At My Sign! - Trade Marks in China from Antiquity to the Early Modern Times' (2005) 87 Journal of the Patent and Trade Mark Office Society 654.

${ }^{89}$ Ibid 660.

${ }^{90}$ If WHITE RABBIT was viewed as the first trade mark, China's trade mark would have existed about 1000 years ago. The WHITE RABBIT mark is mentioned in Ruixue Ran, 'Well-Known Trade Mark Protection in China: Before and After the TRIPS Amendments to China's Trade Mark Law' (2002) 19 UCLA Pacific Basin Law Journal 231, 232.

${ }^{91}$ Yin Liang Liu, The Law of Intellectual Property (Higher Education Publishing House, 2010) 158.

${ }^{92}$ Eckhardt and Bengtsson, above n 87, 215 for a reprint of the WHITE RABBIT trade mark. The authors claim that 'White Rabbit' from the Song Dynasty was 'the earliest documented brand in the world'.

${ }^{93}$ The WHITE RABBIT mark was also seen as an advertising tool because there were words carved on the copper plate promoting the products, indicating their quality and the scope of the business, and warning customers against buying non-genuine needles. It seems to have conformed to the modern concept of a trade mark. The details of the WHITE RABBIT trade mark can be viewed at <http://www.cntme.com/history/478.html>.

${ }^{94}$ Eckhardt and Bengtsson, above n 87, 214. 
last feudal dynasty, the Qing Government passed the Trial Regulation on Trade Mark Registration ${ }^{95}$ and began to offer trade mark protection. The Republic of China was founded in 1911 and continued trade mark registration and protection. Some currently famous trade marks such as ZHANG YU (for wine since 1892), TSINGTAO (for beer since 1903) and HADEMEN (for cigarettes since 1919) appeared in those days. Interestingly, those three brands of products were based on investments by foreigners or overseas Chinese. However, some locally invented and owned brands, such as QUAN JU DE (for Peking duck) and TONG REN TANG (for Chinese herbal medicine), were also registered at that time. ${ }^{96}$ Nevertheless, the trade marks law and registration system were never fully implemented at that time of civil war and foreign invasion. ${ }^{97}$

After the establishment of the People's Republic of China in 1949, the new government promulgated its own trade mark legislation, including the Provisional Trade Mark Registration Regulations in 1950 and the Trade Mark Administration Measures in $1963 .{ }^{98}$ Nevertheless, as a result of the political chaos and economic disruption of the years between late 1958 and 1977, in particular during the period of the Cultural Revolution (1966-1976), China underwent very little economic development or commercial activity. During this time there was really no point in having trade marks, ${ }^{99}$ because China had a rationing system, with basic products and services distributed equally among the people, with only a few regional and professional variations. ${ }^{100}$ In the few shops that sold to the public, people needed coupons to buy basic items such as rice, flour, cooking oils, meat, clothes, and so forth. Consumer products in the market were few and limited, and could be identified without trade marks. Counterfeiting was unheard of under rationing.

\footnotetext{
95 Yin Liang Liu, above $n$ 91, 159.

${ }^{96}$ Yin Liang Liu, above n 91, 158-9.

${ }^{97}$ From 1911 to 1949 China was a war zone: many war lords were fighting each other; the Nationalists (the government at the time) and Revolutionists (the Communist Party) were fighting each other; the Chinese were also fighting the invading Japanese forces. Under the circumstances, it was difficult to establish a proper trade mark registration and protection system.

${ }^{98} \mathrm{~A}$ chronology of the Chinese laws and regulations on intellectual property lists these two pieces of earlier trade mark legislation. See Jing Brad Luo and Shubha Ghosh, 'Protection and Enforcement of Well-Known Mark Rights in China: History, Theory and Future' (2009) 7 Northwestern Journal of Technology and Intellectual Property 119, 127. These two earlier regulations are also mentioned in Yin Liang Liu, above n 91, 159.

${ }^{99}$ The Trade Marks Office was only re-established under the State Administration of Industry and Commerce in 1978 and the registration of trade marks was then resumed.

${ }^{100}$ Yiping Xianzhi, 'Ration System was not Mao's Patent, but Mao Used it to Achieve a Broad Material Equality' (in Chinese), China.com (online), 16 January $2012<\mathrm{http}: / /$ club.china. com/data/thread/1011/2736/38/95/6_1.html>.
} 
Nevertheless, some trade marks were registered in the first 30 years of the People's Republic of China. For example, the TSINGTAO Beer trade mark, adopted in 1903 by a German company, was registered in 1948 during the time of the Republic of China, and it was continuously used after the establishment of the People's Republic of China in 1949. ${ }^{101}$ In 1958 the TSINGTAO trade mark was registered in Hong Kong ${ }^{102}$ and remained alive during the Cultural Revolution because few beers were being produced in and exported from China at the time. TSINGTAO Beer was also one of the first mainland companies listed on the Hong Kong Stock Exchange in 1993. ${ }^{103}$ In 1978 the TSINGTAO Beer trade mark was registered again with the Trade Marks Office with its current logo and words. ${ }^{104}$ In 1997, it was registered with the Madrid Union for international protection. ${ }^{105}$

Trade mark law and trade mark protection were not a concern until the adoption of the Open Door policy in 1978, and the increased awareness of private wealth and ownership thereafter. ${ }^{106}$ The Trade Marks Law of the People's Republic of China $^{107}$ was promulgated in 1982 and became effective on 1 March 1983. Scholars and professionals regard this legislation, which is still in force, as the first properly enacted trade mark law in the People's Republic of China. It was subsequently amended in 1993, 2001 and 2013. The third amendment entered into force on 1 May 2014. Along with the Trade Marks Law, the Implementing Regulations of the Trade Marks Law of the People's Republic of China ${ }^{108}$ were also promulgated, the first of which were adopted by the State Council in 1988. They were subsequently amended in 1993, 1995, 2001 and 2014, with the latest

${ }^{101}$ Deng Ke Mao, 'Discussions on the History and Culture of Tsing Tao Beer' (2013) 18(1) Journal of Nanning Polytechnic 13, 14.

102 August T Horvath et al, 'Chinese Beer Companies in Trade Mark War', March (1999), 11(3) Journal of Proprietary Rights 20.

${ }^{103}$ Henny Sender, 'Companies: Floating without Froth' (1993) 156 (11) Far Eastern Economic Review 43. Also, see 'International Brief: Qingdao Brewery Co: Chinese Concern Said Ready to List Shares in Hong Kong' (1993) Wall Street Journal, Eastern Edition A11.

104 The reason for registering the TSINGTAO Beer trade mark in 1978 was not given by the Tsingtao Brewery Co Ltd in its company profile or any other information related to the company. Since China only began to open up to the outside world in 1978, the registration of TSINGTAO for beer could have been a gesture of confirmation of an existing trade mark.

105 'Tsingtao Brewery Leveraging the Madrid Registration System and Actively Promoting Its Internationalization Strategy' (in Chinese), Qingdao Daily 30 May $2014<\mathrm{http}: / /$ news. 163.com/14/0530/12/9TG8VJ0I00014AED.html .

106 Jing Brad Luo and Shubha Ghosh, above n 98, 129.

107 (People's Republic of China) National People's Congress, Order No 6, 30 August 2013.

108 (People's Republic of China) State Council, Order No 651, 29 April 2014. 
amendments becoming effective on the same day as the new amendments to the Trade Marks Law.

As China started to open its doors wider and attract more foreign investment in the 1980 s, it became necessary to accede to international treaties and to improve the investment environment. Under pressure from investors, trading partners and foreign governments, China acceded to various international treaties, including those relating to trade mark protection. Since 1980 China has acceded to the Convention establishing the World Intellectual Property Organization (China acceded on 4 June 1980); the Paris Convention for the Protection of Industrial Property (China acceded on 19 March 1985); the Madrid Agreement Concerning the International Registration of Marks (China acceded on 4 October 1989); the Nice Agreement Concerning the International Classification of Goods and Services for the Purposes of the Registration of Marks (China acceded on 9 August 1994); and the Protocol Relating to the Madrid Agreement Concerning the International Registration of Marks (China acceded on 1 September 1995). Furthermore, since joining the WTO in 2001, China has been officially complying with the TRIPS Agreement on the protection of trade marks, including well-known trade marks. ${ }^{109}$

However, the protection of well-known trade marks was not incorporated into the trade marks legislation in the first few years. Interim legislation on wellknown marks was promulgated in 1996, but was repealed in 2003 by the Provisions on the Identification and Protection of Well-Known Trade Marks. ${ }^{110}$ Then, in 2009, the State Administration of Industry and Commerce (SAIC) issued the Detailed Rules for Recognition of Well-Known Trade Marks. ${ }^{111}$ The abovementioned 2003 Provisions were amended again in 2014. Further provisions were promulgated recently by the SAIC to prohibit the misuse of intellectual property rights in normal market competition. The Provisions on the Prohibition of the Abuse of Intellectual Property Rights to Exclude or Restrict Competition ${ }^{112}$ were promulgated by the SAIC in 2015. The SAIC Provisions and Rules, as well as articles 13 and 14 of the Trade Mark Law and

\footnotetext{
${ }^{109}$ Ruixue Ran, above n 90, 248-9.

110 (People's Republic of China) State Administration for Industry and Commerce, Order No 5, 17 April, 2003, revised by Order of the State Administration for Industry and Commerce No 66, 3 July 2014.

111 (People's Republic of China) State Administration for Industry and Commerce, Document No 81, 21 April 2009.

112 (People's Republic of China) State Administration for Industry and Commerce, Order No 74, 7 April 2015.
} 
articles 3 and 72 of the Implementing Regulations are the main sources of law dealing with well-known trade marks in China.

\section{FOREIGN INVESTMENT AND CHINA'S INTERNATIONAL OBLIGATIONS ON PROTECTION OF WELL-KNOWN TRADE MARKS}

Economic and legal development in China generally refers to the period after the end of the Cultural Revolution in 1977, because until then there was an economic and legal vacuum. As China's legal reform and development began with the attraction of foreign investment, laws on trade mark registration and protection became necessary. As soon as China opened its doors to the outside world for foreign direct investment (FDI) in 1978, a number of well-known foreign trade marks such as COCA COLA, JEEP, PANASONIC and PEUGEOT appeared in the Chinese market with the inflow of Chinese-foreign joint ventures. ${ }^{113}$ Suddenly the locals were bombarded with beautiful billboards depicting SONY, NATIONAL, TOSHIBA and COCA COLA goods, and others. It felt as if the Chinese people had skipped years in their lives: from never watching television at all to seeing coloured moving pictures; from coveting access to rare and 'luxurious' black and white cameras to being able to take instant coloured photos; from listening to revolutionary songs on the radio to owning brick-sized cassette players; or from drinking only Chinese tea to being able to drink Coca Cola, coffee, foreign beer, and so forth.

Foreign investment and foreign companies had a major impact on China's trade mark laws and the protection of well-known trade marks. The owners of foreign trade marks need to go through all the necessary procedures to have their trade marks registered in China in both the foreign and Chinese language. It is particularly important to register the Chinese version of a foreign trade mark because local consumers like to call foreign trade marks by their Chinese names, regardless of whether these are official Chinese translations or not. Owners who do not immediately realise the value of getting the Chinese version of their trade marks registered as their own, may leave it too late. Pfizer, for example, lost the Chinese translation of its famous VIAGRA mark (WEI GE) to a local Chinese company. ${ }^{114}$

\footnotetext{
113 The manufacturers of COCA COLA, JEEP, PANASONIC and PEUGEOT products were pioneers in setting up joint ventures in China.

${ }^{114}$ Daniel Chow, 'Lessons from Pfizer's Disputes over Its Viagra Trade Mark in China' (2012)

27 Maryland Journal of International Law 82, 91.
} 
On 19 March 1985, China began to comply with the Paris Convention for the Protection of Industrial Property. Accession to the Paris Convention was seen as a most important step towards a proper intellectual property protection system which could be accepted by the developed countries. As a member state of the Paris Convention, China would be under an international obligation to protect foreign trade marks, as well as offering special protection to well-known foreign trade marks. Article 6bis of the Paris Convention requires China to protect a trade mark with well-known trade mark status regardless of whether it is registered in China. ${ }^{115}$ However, this protection was not incorporated into the Trade Mark Law until the 2001 Amendment. Nevertheless, the well-known trade mark principle was complied with by the Chinese courts in practice, in particular in the 1987 PIZZA HUT decision. ${ }^{116}$ The PIZZA HUT trade mark was originally registered by an Australian company ${ }^{117}$ in China in 1985. In 1987 the Trade Mark Office of the SAIC confirmed that PIZZA HUT was a wellknown trade mark, and thus the original registration was cancelled and the owner of the trade mark, US Pizza Hut International Co Ltd, was allowed to register the PIZZA HUT trade mark one year later. Thus adoption of the article 6bis principle significantly improved the position of foreign trade mark owners in China even though 'in practice it was very difficult to get protection for unregistered well-known trade marks that have not been used in China'. ${ }^{118}$

China's international obligation to protect well-known trade marks was not limited to its obligations under the Paris Convention. Since China joined the WTO in 2001, it also accepted the principles embodied in the TRIPS Agreement. The TRIPS Agreement expanded protection of well-known trade marks and prohibited, under certain conditions, people from using (or registering) others' well-known trade marks in connection with both similar and dissimilar goods or services. ${ }^{119}$ Under articles $16(2)$ and 16(3) of the TRIPS Agreement, China is required to protect unregistered well-known foreign trade marks in relation to similar classes of goods or services, as well as registered well-known foreign trade marks for dissimilar classes of goods or services. ${ }^{120}$ Further to the adoption of the TRIPS Agreement, China also follows WIPO's

\footnotetext{
115 Jessica C Wong, 'The Challenges Multinational Corporations Face in Protecting their WellKnown Trade Marks in China' (2006) 31 Brooklyn Journal of International Law 937, 946.

116 Jing Brad Luo and Shubha Ghosh, above n 98, 155-6.

${ }^{117}$ Edward E Lehman, Camilla Ojansivu and Stan Abrams, 'Well-Known Trademark Protection in the People's Republic of China - Evolution of the System' (2002) 26 Fordham International Law Journal 257, 259.

${ }^{118}$ Ruixue Ran, above n 90, 237.

119 Breann M Hill, 'Achieving Protection of the Well-Known Mark in China: Is There a Lasting Solution?' (2009) 34 Dayton Law Review 281, 286.

${ }^{120}$ Jessica C Wong, above n 115, 946-7.
} 
Joint Recommendation Concerning Provisions on the Protection of WellKnown Marks (WIPO's Joint Recommendation). ${ }^{121}$

Protection of well-known trade marks was not a new issue in China. Less than 10 years after China opened its doors to the outside world, ${ }^{122}$ the issue of protecting well-known trade marks put China in the world spotlight. The abovementioned 1987 PIZZA HUT case was to be China's first experience of upholding a foreign well-known trade mark. Although a number of other foreign trade marks obtained well-known trade mark status later, such as LUX (UK), MARLBORO (US), VOLVO (Sweden), LANCÔME (France), media attention was not focused on well-known trade marks until 2004, when the American Starbucks company was fighting for its trade mark's Chinese translation, XING BA KE, in Shanghai. ${ }^{123}$ As in the PIZZA HUT case, the defendant, Shanghai Xing Ba Ke Coffee Ltd, was unable to retain its trade mark registration in China. ${ }^{124}$ After winning the case, the American Starbucks Corporation registered the STARBUCKS' Chinese name XING BA KE as its trade mark in China and made a big move into the Chinese market.

China adopted the 'First to File' ${ }^{125}$ system in trade mark registration, which allowed 'trade mark squatting'. ${ }^{126}$ It was easy to demonstrate that a foreign trade mark had never been filed in China, and was thus new and registrable. This type of scenario occurred when a foreign direct investment (FDI) company finally decided to make an FDI and take its operation into China, only to find that its valuable trade mark had been 'legally' registered by a Chinese company in both the Chinese and foreign languages, as in the earlier-mentioned VIAGRA case. The reported 'trade mark squatting' cases have mainly related to American trade marks such as KARDASHIAN, J. CREW, JUSTIN BIEBER

\footnotetext{
${ }^{121}$ China joined the World Intellectual Property Organization (WIPO) on 3 June 1980.

${ }^{122}$ China adopted the Open Door Policy in December 1978 at the Communist Party's Third Session of the $11^{\text {th }}$ National Congress.

${ }^{123}$ In 2004, Starbucks Corporation sued a Hong Kong businessman based in Shanghai for illegal registration of the Chinese translation of STARBUCKS in China. STARBUCKS was confirmed as a well-known trade mark and the Hong Kong businessman, who had operated two shops as XING BA KE in Shanghai, lost the court case to the American company.

${ }^{124}$ Mary K Alexander, 'The Starbucks Decision of the Shanghai No.2 Intermediate People's Court: A Victory Limited to Lattes?' (2008) 58 Case Western Reserve Law Review 881, 898.

125 Under the 'First to File' policy, whoever submits the applications first with the Trade Marks Office and satisfies all the registration criteria will become the recognised owner of that trade mark.

${ }^{126}$ Trade Mark Law of the People's Republic of China (People's Republic of China) National People's Congress, 23 August 1982, arts 30 and 31; Regulations for the Implementation of the Trade Mark Law of the People's Republic of China, (People's Republic of China) State Council of People's Republic of China, Order No 358, 3 August 2002, arts 18 and 19.
} 
and ANGRY BIRD. ${ }^{127}$ Once those trade marks had been registered 'legally' in China by the non-owners, it was not a simple matter for the Trade Marks Office to de-register 'bad faith' registrations as provided by article 32 of the Trade Marks Law. ${ }^{128}$

A good example of a case decided in favour of the Chinese company was the 2011 iPAD case. ${ }^{129}$ American trade mark owners were advised time and time again about the importance of making their trade marks well-known in China, ${ }^{130}$ because not only was iPAD registered there, but also aPAD to zPAD. In 2011 the Trade Mark Office and the Trade Mark Review and Adjudication Board stopped malicious applications for 233 foreign well-known trade marks by one individual Chinese applicant, Ye Rongjie. ${ }^{131}$ In addition, about 700 bad-faith applications for foreign well-known trade marks, including GUCCI, KENZO, TOMMY HILFIGER, DIOR, SHERATON and HYATT, were rejected in opposition procedures. ${ }^{132}$

However, since 1985 and pursuant to its commitments under the Paris Convention, China's recognition and protection of well-known trade marks has presented an exception to the 'First to File' registration system. In 2011, the Trade Mark Office recognised 693 well-known trade marks directly or in opposition procedures. ${ }^{133}$ A further 968 well-known trade marks were recognised in 2012. In 2013, another 330 were determined in review cases, and

\footnotetext{
127 David Pierson, 'Trademark Squatting in China Doesn't Sit Well with U.S. Retailers', Los Angeles Times, 28 March 2012 <http://articles.latimes.com/2012/mar/28/business/la-fi-chinatrademark-squatting-20120328/2>.

128 Trade Marks Law art 32: 'The trade mark application shall neither infringe upon another party's prior existing rights, nor be an improper means to register a trade mark that is already in use by another party and enjoys substantial influence'.

${ }^{129}$ Arthur Tan-Chi Yuan, 'Exploring Apple's iPad Trade Mark Blunder: Chinese Trade Mark Approval Procedure is a Trade Mark Protection Safeguard or Another National Protectionism?' (2012) 11 John Marshall Review of Intellectual Property Law 776, 778.

${ }^{130}$ Breann M Hill, 'Achieving Protection of the Well-Known Mark in China: Is There a Lasting Solution?' (2009) 34 Dayton Law Review 287.

131 Trade Mark Office/Trade Mark Review \& Adjudication Board of the SAIC, State Administration for Industry and Commerce, Annual Development Report on China's Trade Mark Strategy 201114.

132 Trade Mark Office/Trade Mark Review \& Adjudication Board of the SAIC, State Administration for Industry and Commerce, Annual Development Report on China's Trade Mark Strategy 201213.

${ }^{133}$ Annual Development Report on China's Trade Mark Strategy 2011, above n 131, 3.
} 
147 previously determined well known trade marks were re-determined, including LOUIS VUITTON, PORSCHE and MARLBORO. ${ }^{134}$

Before the amendments to the Trade Mark Law in 2001, if a foreign trade mark owner wanted to challenge a registered trade mark on the grounds of wellknown trade mark status, it had to supply the Trade Marks Office with documents showing registration and usage of the trade mark in China. ${ }^{135}$ The requirements could present difficulties for foreign trade mark owners in documenting 'well-known status' as they might not have established investment activities or business operations in China. Since 2001, however, foreign trade mark owners have found it easier to prove that their trade marks were 'well-known', because they are no longer required to show that their trade marks have been registered or used in China.

\section{The Rush to REgister LOCALLY WELL-KNOWN TRADE MARKS IN ChINA}

Well-known trade mark status gives the owner two advantages in China: one is the protection of the marks from trade mark squatting, and the other is better market recognition in the consumer goods/services environment. ${ }^{136}$ Among local businesses, the latter advantage has also been thoroughly understood and widely utilised. ${ }^{137}$ Seeing this advantage, local trade mark owners rushed to have their trade marks registered or recognised as 'well-known trade marks'. Local entrepreneurs thereby expanded the use of well-known trade marks and treated a well-known trade mark as an honour, not a legal concept. ${ }^{138}$ Many local governments ${ }^{139}$ and their star companies have viewed the number of well-

134 Trade Mark Office/Trade Mark Review \& Adjudication Board of the SAIC, State Administration for Industry and Commerce, Annual Development Report on China's Trade Mark Strategy 2013, 29.

135 Ruixue Ran, 'Recognition of Well-Known Trade Marks by Administrative Authorities' (2003) China Law and Practice 58, 59.

136 The court cases on well-known trade marks have attracted enormous media attention and public awareness for the trade marks involved and their foreign owners.

137 Justin Davidson and David W Cheng, 'China Question: How Do I Get My Trade Mark Recognised as Well Known?' (2012) 26(3) China Law and Practice 9.

${ }^{138}$ Annual Development Report on China's Trade Mark Strategy 2013, above n 134, 34.

${ }^{139}$ Local governments use the numbers of well-known trade marks to judge the achievements of their local economy; thus they actively promote and encourage local businesses to obtain wellknown trade marks or local 'famous' trade mark status. Until recently, the authorities also promoted a category of locally 'famous' trade marks. This gave second tier status to marks not yet well-known nationally, but with potential to become well-known trade marks. This can be seen in the large number of local administrative decrees on the promotion of well-known and famous trade marks generated by the local governments at all levels in China. Examples are: 
known trade marks obtained as their key political achievement and economic performance indicator. ${ }^{140}$ Financial assistance and rewards have been given to local companies as incentives for obtaining well-known trade mark status. ${ }^{141}$ For example, Jilin Provincial Government in 2005 set aside 30 million yuan as an incentive fund for well-known trade marks and set as its five-year goal the registration of 22 well-known trade marks and 230 famous trade marks within the province. ${ }^{142}$ Gaining well-known trade mark status has in this way almost become an end purpose, not a by-product of the improved quality and increased market share of any goods or service. By misusing the well-known trade marks label for the purposes of promotion, companies have in fact created unfair competition. ${ }^{143}$ This is recognised by intellectual property lawyers working in China. ${ }^{144}$

There are two ways of getting a trade mark registered or recognised as a wellknown trade mark. One is to go through the Trade Marks Office or the Trade Mark Review and Adjudication Board. ${ }^{145}$ Another way is to take a case to an intermediate peoples' court to get a disputed trade mark recognised as a wellknown trade mark. The first way is considered 'expensive, difficult and timeconsuming, ${ }^{146}$ because the applicants need to submit sufficient supporting

The Measures of Xi'an Municipality for the Recognition and Protection of Well-Known Trade Marks (adopted by the Xi' an Municipal government on 8 July 2009); The Notice of Liao Ning on Further Improving Efforts on Creations of Well-Known Trade Marks (adopted by Liao Ning Provincial Government on 2 December 2003).

${ }^{140}$ Linda Chang and Elliot Papageorgiou, 'Three Ways to Rescue the Trade Mark Law' (2012) 26(4) China Law and Practice 4.

141 Tieqiao Ye, 'Fraudulent Well-Known Trade Marks Lured under the Substantial Financial Rewards', China Youth Daily (online), 14 December 2009 <http://www.cyol.net/ zqb/content/2009-12/14/content_2980651.htm>.

142 The Measures of Jilin Provincial Government on Encouraging and Rewarding Well-Known Trade Marks (Jilin Measures) adopted on 19 December $2005<$ Lexiscn.com, Ji Zheng Ban Fa [2005] No 55> or <https://hk.lexiscn.com/law/content.php?provider_id=1\&isEnglish=N\& origin_id=350647\&eng=0\&isEnglish $=$ N\&keyword $=5 Z$ ZJ 5pS $\% 2 F 5 Y q e 5 Y \% 2 B R W z I w M D V$ dLOWKnuWPkSzlip7lj5Es5ZCJ5pS\%2FLOWQieaUvyw1NeWPtywyMDA1LDIwMDUs5Y \%2B3LOWPtyw1NSw1NQ\%3D\%3D\&t_kw=5ZCJ5pS\%2F5Yqe5Y\%2BRWzIwMDVdLO WKnuWPkSzlip7lj5Es5ZCJ5pS\%2FLOWQieaUvyw1NeWPtywyMDA1LDIwMDUs5Y\%2 B3LOWPtyw1NSw1NQ\%3D\%3D>.

${ }^{143}$ Annual Development Report on China's Trade Mark Strategy 2013, above n 129, 34.

${ }^{144}$ Linda Chang and Elliot Papageorgiou, above n 140, 4.

${ }^{145}$ Trade Mark Law art 2.

${ }^{146} \mathrm{Na}$ Luo and Xiao Bing Yao, 'Judicial Recognition of Well-Known Trade Marks Shall Not Fall outside Judicial Inspections', Procuratorate Daily, 16 July $2010<\mathrm{http}: / /$ newspaper.jcrb. com/html/2010-07/16/content_49367.htm>. 
evidence and materials to prove that the trade mark is 'well-known'. ${ }^{147}$ Quite a few foreign well-known trade marks have gone along the administrative recognition path with the Trade Marks Office as recorded by the Annual Development Reports of the Trade Mark Office and the Trade Mark Review and Adjudication Board. ${ }^{148}$ The second way requires the plaintiffs to take the disputed trade marks to court to expand trade mark protection to a dissimilar class of goods or services. To achieve the extended protection, a plaintiff has to request the court to confirm the well-known status of its trade mark. This judicial recognition of well-known trade marks has been regarded as 'time efficient and simple ${ }^{149}$ by practising lawyers in China. Basically, two aims can be achieved by this process: the confirmation of well-known trade marks, and the prevention of the use by others of the trade marks in a class of goods/services different from that to which the original registration applied. Many Chinese trade mark owners have gone down this second path of judicial recognition.

However, the judicial recognition of well-known trade marks has been misused in the past, with the creation of a number of artificial 'well-known trade marks' ${ }^{150}$ In order to make a case to the court for judicial recognition, the trade mark owners needed to claim an infringement, that is, to produce a defendant. Even if there had been no infringement, the owner would artificially create an infringer. ${ }^{151}$ The owner thereby created an opportunity to have its trade mark confirmed as a well-known trade mark. One particular case widely written about in both Chinese and English was Kanwan Fine Chemical Industry Co Ltd $v$ Li Chaofang, ${ }^{152}$ in which the trade mark owner's solicitor deliberately helped his client to 'create a defendant'. Although KANWAN was recognised as a well-known trade mark by way of this exercise in 2006, the decision was

\footnotetext{
${ }^{147}$ Trade mark owners need to collect the necessary documents required under art 14 of the Trade Mark Law for administrative recognition of well-known trade marks.

${ }^{148}$ Some of the well-known foreign trade marks such as GUCCI, LV, KENZO, DIOR, HYATT, PORSCHE and MARLBORO etc were named in the Annual Development Reports on China's Trade Mark Strategy of 2011, 2012 and 2013, above nn 131, 132 and 134.

149 Justin Davidson and David W Cheng, above n 137, 9.

150 Chiang Ling Li, China's New Well-Known Mark Regime (9 October 2015) <https://hk. lexiscnweb.com/clr/view_article.php?clr_id=90\&clr_article_id=1086>.

${ }^{151}$ Xinian Tao, 'Zhejiang: Well-Known Trade Marks Are Not So Known; Recognitions Were Obtained via Faking Court Proceedings', People's Daily (Online), 12 February 2009 <http://ip.people.com.cn/GB/8791172.html>.

152 On 29 May 2006, the Kanwan case was brought to a court due to an infringement of the KANWAN trade mark by a domain name, <www.kanwan.com.cn>, registered in the name of the defendant. KANWAN was confirmed as a well-known trade mark by the court after the completion of the infringement hearing.
} 
overruled once the truth was revealed and the original judgment was reversed. ${ }^{153}$

In March 2009 another similar case, that of PIAO LIU DAO, ${ }^{154}$ was decided. The owner of the PIAO LIU DAO trade mark was a Chinese company making clothes in Shishi City, Fujian Province. In 2006, the owner sued an infringer of its trade mark in Fuzhou Intermediate People's Court of Jiangxi Province for the unauthorised sale of fake PIAO LIU DAO clothes and accessories. Fuzhou Intermediate People's Court confirmed PIAO LIU DAO as a well-known trade mark based on the documentary evidence of stamps, tax returns, advertising expenses and so on, submitted by the plaintiff. Three years later, in 2009, the two major shareholders of the Piao Liu Dao company broke up. While they were disputing the ownership of the company, the manipulation that had been involved in getting their trade mark recognised as a well-known trade mark emerged. ${ }^{155}$ Subsequently, journalists found that all the documents used for claiming PIAO LIU DAO as a well-known trade mark had been forged by the plaintiff company. ${ }^{156}$ It was also highly suspicious that the defendant's brother was paid RMB 110000 before the infringement case was initiated. ${ }^{157}$

This case caused the business community to view well-known trade marks with suspicion. In Quanzhou District where Shishi City is located, there were over 70 well-known trade marks in the entire District (including PIAO LIU DAO). More than half of these, about 40 well-known trade marks, had been obtained via judicial recognition. ${ }^{158}$

\footnotetext{
${ }^{153}$ Ai Guo Zhang, 'The Judicial Determination and Protection of Well-Known Marks in China in the 21st Century' (2010) 48 University of Louisville Law Review 959, 965.

${ }^{154}$ Saiming Duan, 'Judicial Recognition Has Changed the Nature of Well-Known Trade Mark' Xinhua News Wire (online), 25 March $2009<\mathrm{http}: / /$ news.xinhuanet.com/comments/200903/25/content_11068768.htm>.

155 'Well-Known Trade Mark 'Piao Liu Dao' of Shishi has been Cancelled', Strait Metropolitan Newspaper (online), 1 April 2009 <http://news.66163.com/2009-04-01/231429.shtml>.

${ }^{156}$ Zheng Liang, 'The Investigation on Cheating Methods Used by 'Piao Liu Dao's in Obtaining Well-known Trade Mark', Xinhua News Wire (online), 24 March 2009 <http://news.xinhuanet.com/newscenter/2009-03/24/content_11061640.htm>.

${ }^{157}$ Ibid.

${ }^{158}$ Cheng Bing (Editor), A Special Legal Report by the Legislative Affairs Office of the State Council of the People's Republic of China on 'Company cheated for well-known trade mark and all forged documents were accepted', Legal Information Online of the State Council, No.24 of 2009, 13 March 2009 <http://www.chinalaw.gov.cn/article/dfxx/dffzxx/sh/zffzcyzb/ 200903/20090300129673.shtml>.
} 
The call ${ }^{159}$ for tightening up recognition of well-known trade marks was heard and addressed in the amendments to the Trade Mark Law ${ }^{160}$ and its Implementing Regulations. ${ }^{161}$ Among the amendments, it is noteworthy that the 'well-known trade mark' was redefined by article 13 of the Trade Mark Law to mean well-known by the relevant public, ${ }^{162}$ in accordance with the Paris Convention. ${ }^{163}$ In addition, the Trade Mark Law addressed the issue of bad faith registration and protection of well-known trade marks. ${ }^{164}$ The most important amendment in that regard is that article 14 adds a concluding sentence stating that "producers and operators shall neither use characters such as "well-known trade mark" in the goods, on the packaging or vessels nor apply the same for advertising, exhibition or other commercial activities'. This new requirement literally bans the use of the 'China Well-Known Trade Mark' designation in labelling and advertising ${ }^{165}$ and takes away the superior image or position of a well-known trade mark in product marketing or business promotion. If an owner does not comply with these requirements and uses the term 'well-known trade mark' commercially in advertising, he or she may be fined RMB $100000 .{ }^{166}$ Without product labelling or service branding, the incentive to obtain the well-known trade mark status artificially is diminished. Article 14 of the Trade Mark Law maintains the requirement that applicants provide supporting documents in order to obtain a well-known trade mark. However, in

${ }^{159}$ One People's Representative to the National People's Congress (the NPC), Mr Zong Qinghou, who is also the owner of the famous company Wahaha, had suggested on 8 March 2010 in the China News Online that the Trade Mark Law should be amended to reduce the numbers of wellknown trade marks. He subsequently suggested more amendments to the Trade Mark Law in the following sessions of the NPC: <http://www.chinanews.com/cj/cj-gncj/news/2010/0308/2157226.shtml>.

${ }^{160}$ Arts 13 and 14 of the Trade Mark Law had been amended to give a better definition of a 'wellknown trade mark' and to aim at rectifying the improper use of well-known trade marks in China.

161 Arts 3 and 72 of the Implementing Regulations of the Trade Mark Law provide a bit more detail to arts 13 and 14 of the Trade Mark Law.

162 Article 2 of the SAIC's amendments to the Provisions on the Identification and Protection of Well-known Trade Marks (Revised in 2014) also reiterated the definitions of the 'well-known trade marks' and the 'relevant public'.

163 'Managing Intellectual Property, Sponsored Discussion: Moving Fast under China's New Trade Mark Law,' 11 May 2014 <http://www.managingip.com/Article/3340411/Sponsoreddiscussion-Moving-fast-under-Chinas-new-Trademark-Law.html>.

${ }^{164}$ Weijun Zhang, Lizhou Wei and Yanbing Li, 'The Third Revision of Chinese Trade Mark Law - Analysis and Comment' (2014) 45(5) International Review of Intellectual Property and Competition Law 556, 569.

165 Paul Kossof, 'Chinese National Well-Known Trade Marks and Local Famous Trade Marks in Light of the 2013 Trade Mark Law: Status, Effect, and Adequacy' (2013) 13 John Marshall Review Intellectual Property Law 225, 228.

166 'Managing Intellectual Property, Sponsored Discussion, above n 163. Art 53 of the Trade Mark Law imposes a fine of RMB 100000 for breach of art 14. 
order for a mark to be determined to be well-known, not all of the factors need to be satisfied. The distinctiveness of the mark and its level of recognition must be taken into consideration. ${ }^{167}$ Clearly, these amendments have brought articles 13 and 14 of the Trade Mark Law into line with the provisions in TRIPS and the WIPO Joint Recommendation. ${ }^{168}$

\section{CONCLUSION}

Both China and Indonesia have had a turbulent history over the last century. China experienced a transition from the last days of the Qing dynasty over the period of nationalist China and Japanese occupation to the Cultural Revolution and, finally, the gradual opening up of the economy since the late 1970s. Indonesia over the same period saw Dutch colonialism give way to Japanese occupation. Independence then followed a brief return of the Dutch after World War II. An economically nationalist self-reliance policy was implemented during the first two decades after independence, and, since the second half of the 1960s, there developed the gradual opening up of more and more sectors in an increasingly export-oriented, liberal economy. Although intellectual property protection in general and trade mark protection in particular were, of course, affected by these turbulences, it is remarkable that the trade marks of some businesses founded in the days of the Qing dynasty in China, and of Dutch colonial rule in Indonesia, are still not only in use and well-known, but have in fact become national icons. TSINGTAO Beer in China and the cigarette brands DJI SAM SOE and BENTOEL, as well as the coffee brands SINGA and KAPAL API, are excellent examples. Also, while well-known brand owners have often struggled in the courts to defend their marks, these local flagship brands have apparently experienced little imitation and have been fairly well respected. Because of their long history and early registration, they have not experienced the problem of 'trade mark squatting' to the same extent as foreign and multinational latecomers on the domestic market.

In both countries, following the TRIPS Agreement, not only are well-known trade marks protected for similar goods or services, but protection is also granted to registered well-known trade marks used for dissimilar goods or services. In both countries, details are regulated in implementing legislation, with much discretion left to the courts. This is particularly the case in Indonesia, where practitioners criticise the fact that the relevant government regulation has

\footnotetext{
${ }^{167}$ Chiang Ling Li, above n 150.

${ }^{168}$ Weijun Zhang, Lizhou Wei and Yanbing Li, above n 164, 570.
} 
never been issued. Foreign and multinational companies initially had to struggle in local courts in this field, although this has changed.

A peculiar problem in China is the need in many cases to register Chinese translations of well-known foreign brands. Only recently have the courts come to accept that these should belong to the foreign owner rather than the local user, but this issue is still not completely settled. In Indonesia, the protection of well-known trade marks is now a routine decision for the courts, but a potential danger is the mechanistic use of the principles. Practitioners in Jakarta frequently remind the government that the promised implementing guidelines are urgently needed. ${ }^{169}$

In China, a phenomenon has arisen of businesses pursuing for their trade marks the status of being nationally 'well-known', or else locally 'famous', ${ }^{170}$ should the marks not yet be 'well-known' at the national level. Thus, by the end of 2012, the Trade Marks Office had recognised 4486 well-known trade marks ${ }^{171}$ nationally, while the local governments in different regions had recognised 40914 'famous' trade marks. ${ }^{172}$ Many of these were printed on product packaging and labelling. Since 2013 a tightening up of this flourishing 'wellknown' or 'famous' trade mark registration has been carried out by the administration and the legislative authorities. The administrative authorities have begun to issue instructions that the accumulation of a number of such marks should not be seen as an achievement in itself. ${ }^{173}$ The legislation has also been updated to ensure that well-known trade mark status is no longer used simply for the purpose of marketing the status itself. Henceforth, well-known trade mark status should be a 'shield', not a 'sword' in China.

The comparison shows that well-known trade marks are not only important for foreign firms, but also an increasingly vibrant tool for local enterprises with potential for SMEs that want to promote local products. As the case law indicates, however, 'trade mark squatting' remains an issue largely for foreign and multinational latecomers to the local market, who have to overcome a lack of local knowledge in the case of specialised products and, sometimes, battle the translation of their marks into other languages.

\footnotetext{
${ }^{169}$ Prudence Jahja and Andrew Diamond, 'What Indonesia Needs to Do to Join the World IP Community' (2013) 230 Managing Intellectual Property 40; 'Wilayah Abu-Abu Merek Terkenal', above n 83 .

${ }^{170}$ Kossof, above n 160, 243.

${ }^{171}$ Annual Development Report on China's Trade Mark Strategy 2012, above n 132, 2.

172 Ibid 98.

${ }^{173}$ Ibid 34.
} 